International Journal of Economics, Business and Accounting Research (IJEBAR)

Peer Reviewed - International Journal

Vol-4, Issue-1, 2020 (IJEBAR)

E-ISSN: 2614-1280 P-ISSN 2622-4771

https://jurnal.stie-aas.ac.id/index.php/IJEBAR

\title{
THE INFLUENCE OF WORK ENVIRONMENT AND MOTIVATION ON EMPLOYEE PERFORMANCE IN WOOD FACTORY
}

\author{
Teddy Adrianto ${ }^{1}$, Joshua Pandapotan Siringoringo ${ }^{2}$ \\ Master of Management in the Faculty of Economics and Business, Mulawarman University \\ Email: lauwtunging@hotmail.com
}

\begin{abstract}
:
This research was conducted to analyze the influence of the environment and motivation on employee performance. The sample used was saturated sampling with 50 respondents. The results of this study indicate that the work environment and motivation have a significant effect on the performance of the Timber Mill with work motivation as the dominant variable. This research uses a quantitative approach and this research data is obtained through a questionnaire. The result of this research shows that the work environment has a significant effect on employee performance in wood mills, and also motivation has a significant effect on employee performance in wood mills.
\end{abstract}

Keywords: $\quad$ Work Environment, Motivation, Employee Performance

\section{Introduction}

On current era of globalization, every company is required to have good human resources. A good human resource will provide and increase effectiveness which is also good for the company and can compete with other companies. A company that wants to achieve its goals must provide motivation and pay attention to the work environment in order to produce employees who work efficiently and effectively. By providing comfort when working for employees through the work environment will determine the level of employee performance. (Sugiyarti, 2012) The work environment is everything that is around the worker who can influence himself in carrying out the tasks he is carrying.

An environment is said to be good if the environment is suitable if the employees feel comfortable in carrying out activities carried out optimally. Poor work environment can demand more labor and time and do not support the achievement of an efficient work system design (Sedarmayanti, 2007) So it can be concluded that the work environment is everything that exists around employees when working both physically and non-physically and directly indirectly that can affect employees and their work at work.

In addition to the work environment that affects employee performance motivation also affects employee performance. Motivation is important for individual achievement. Motivation is the process of influencing or encouraging from outside on a person or work group so that they want to carry out something that has been set (Samsudin, 2010) employees who have enthusiasm are the result of a strong level of motivation and vice versa employees who have low morale are the result of lack of motivation. Motivation is the driving force for someone to contribute as much as possible for the success of the organization to achieve its goals (Siagian, 2014) so it can be said that motivation is an encouragement that makes someone do the job they want without being forced so that the work done goes well and produces satisfactory performance .

Employee performance is important to be studied in order to improve the performance of a company. Companies do not always experience an increase in performance but also experience a 
decrease in performance, from the results of interviews conducted there are problems that can reduce performance is during the fasting month. The decrease in productivity due to the influence of the fasting month is caused because employees who work while fasting tend to produce lower performance. So it can be concluded that a company's productivity is influenced by the performance of employees who play an important role in achieving company goals.

Problem formulations in this study are: Does the work environment affect the performance of employees at the Timber Mill?, Does motivation affect employee performance at the Timber Mill?

Work must be supported by several aspects, one of which is the work environment and motivation. The work environment can be very influential on the employee's physical and employee psychology because no matter how motivated the employee is, performance will be poor if there is no supportive environment. Likewise with motivation where motivation is the achievement of something. This is supported by penelit ian conducted by (Son, 2013), den gan title of influence environmental work to employees performance at PT. Naraya Telematics Malang. The results of the study are the work environment has a significant simultaneous effect on employee performance. While research conducted by (Iskandar, 2012) on the effect of motivation and work environment on the performance of Kendal District High School teachers, the results showed that motivation and work environment had a positive and significant effect on the performance of high school teachers. Then research from (Bachtiar, 2011) with the title Effect of Motivation and Work Environment on Employee Performance at PT. Aqua Tirta Investama in Klaten, the results showed motivation and work environment influence the performance of employees at PT. Aqua Tirta Investama Klaten and there is a joint influence between the environment and motivation on the performance of the employees of PT. Aqua Tirta Investama Klaten.

\section{Hypothesis}

- It is suspected that the work environment has a positive and significant impact on employee performance in wood mills

- It is suspected that motivation has a significant effect on employee performance in timber mills

\section{Conceptual framework}

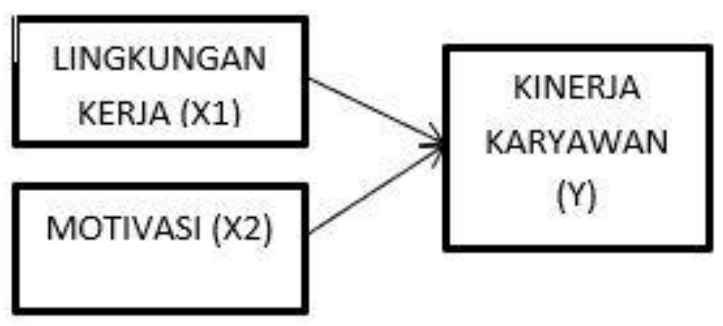

\section{Research methods}

This type of research uses a quantitative approach, quantitative research methods can be interpreted as a research method based on the philosophy of positivism, used to examine populations and specific samples, sampling techniques are generally carried out randomly, data collection using research instruments, quantitative data analysis / statistics with the aim to test the hypotheses that have been set (Sugiyono, 2013). because the data obtained in the form of 
International Journal of Economics, Business and Accounting Research (IJEBAR)

Peer Reviewed - International Journal

Vol-4, Issue-1, 2020 (IJEBAR)

E-ISSN: 2614-1280 P-ISSN 2622-4771

https://jurnal.stie-aas.ac.id/index.php/IJEBAR

numbers and processing using statistical analysis. Data collection techniques used in the form of a questionnaire filled out by the employees of the Timber Factory production. The population in this study were employees of the Timber Factory production section.

According to (Sugiyono, 2007) heed the population as a generalization area consisting of objects / subjects that have quality and drawn conclusions. So popula si in this study is a production employee at a lumber mill, amounting to 50 people. The sampling technique used in this study is to use saturated sampling. The saturation sampling technique is a sampling technique when all members of the population are used as samples. So the sample in this study were 50 employees of the production department. Data collected in this study are primary data.

\section{Results and Discussion}

Table 1. Multiple Linear Regression Test Results

\begin{tabular}{|c|c|c|c|c|c|}
\hline \multicolumn{2}{|c|}{ VARIABLES } & \multirow{2}{*}{$\begin{array}{l}\text { Regression } \\
\text { Coefficient } \\
\text { (B) }\end{array}$} & \multirow{2}{*}{$\begin{array}{l}\mathrm{t} \\
\text { count }\end{array}$} & \multirow[t]{2}{*}{ Sig. } & \multirow[t]{2}{*}{ Information } \\
\hline Related & Free & & & & \\
\hline \multirow{3}{*}{$\begin{array}{c}\text { Employee } \\
\text { Performance } \\
\text { (Y) }\end{array}$} & Constant & $\mathbf{0 , 5 3 7}$ & & & \\
\hline & $\begin{array}{l}\text { Environment } \\
\text { work (X1) }\end{array}$ & 0.226 & 2,567 & 0.013 & Significant \\
\hline & $\begin{array}{l}\text { Motivation } \\
\text { (X2) }\end{array}$ & 0.636 & 6,892 & 0,000 & Significant \\
\hline \multicolumn{2}{|c|}{$\begin{array}{l}\text { R Square } \\
\text { Adjusted R Square } \\
\text { TTable } \\
\text { Sig.F } \\
\alpha \\
\text { N }\end{array}$} & \multicolumn{4}{|l|}{$\begin{array}{l}=\mathbf{0 . 6 6 0} \\
=\mathbf{0 . 6 4 5} \\
=\mathbf{2 , 0 0 0} \\
=\mathbf{4 5 , 6 0 7} \\
=\mathbf{3 . 2 7} \\
=\mathbf{0 , 0 0 0} \\
=\mathbf{0 . 0 5} \\
=\mathbf{5 0}\end{array}$} \\
\hline
\end{tabular}

Source: Data processed

From table 1 obtained by the reg receipt equation, namely: $\mathrm{Y}=0.537+0.636 \mathrm{X} 1+0.226 \mathrm{X} 2$

Based on the results of the equation, it can be explained as follows:

a. Constants (a) $=0.537$, showing the amount of performance, if motivation and work environment is 0 , then the amount of performance is 0.537 .

b. The work environment regression coefficient (b1) is 0.226 , indicating the magnitude of the influence of the work environment on performance, the regression coefficient that is positive indicates the work environment has a direct effect on performance, which means that any improvement in the work environment will cause an increase in performance.

c. The regression coefficient of motivation (b2) was 0.636 , indicating the magnitude of motivation on performance, the regression coefficient that was positive showed motivation had a direct effect on performance, which meant that any increase in motivation would cause an increase in performance. 


\section{Discussion}

To test hypothesis 1 which states that the work environment (X1) has a significant effect on employee performance $(\mathrm{Y})$ using the $\mathrm{t}$ test. $\mathrm{T}$ test analysis results obtained significance value of the $t$ work environment of 0.013 smaller than $\alpha=0.5(0.013<0.05)$, so it is proven that the work environment variable (X1) has a significant effect on employee performance (Y). With research the first hypothesis is statistically accepted.

To test hypothesis 2 which says that motivation (X2) has a significant effect on employee performance $(\mathrm{Y})$ using $\mathrm{t}$ test. The results of the $\mathrm{t}$-test analysis showed that the significance value of motivation $\mathrm{t}$ was 0,000 smaller than $\alpha=0.5(0,000<0.5)$, so it was proven that the motivation variable (X2) had a significant effect on employee performance (Y). Thus the second hypothesis is statistically accepted.

\section{Effect of Work Environment on Employee Performance}

The working environment affects significan on employee performance, indicated significantly smaller value of $\alpha=0.5(0.013<0.05)$. This shows that in order to manage human resources effectively, one of the factors that companies must pay attention to is the work environment that can influence the formation of potential resources. A good work environment is a work environment that provides a sense of comfort for employees to carry out work activities that ultimately affect the performance achieved. A good and pleasant work environment can increase morale in the company and also encourage employees to work better, so that the implementation of production in a company will run well which in turn has a positive effect on employee performance.

The condition of the work environment includes equipment and work facilities (physical work environment) and non-physical work environment, including work environment and workplace environment. If the condition is not good then it will cause an unpleasant environment so that the sense of boredom and fatigue often occurs and results in employee loyalty to the company will decrease and affect the performance of employees that can hinder the business or plan predetermined by the company so that the goals of the company will not be achieved.

As is known that the performance of employees in carrying out their duties is influenced by many factors. One factor is the work environment. Work environment factors are very important factors therefore the work environment must be endeavored such that it has a positive influence. Creation of a good work environment to safeguard the health of workers in vision, hearing and accident disorders. With the prevention of a bad work environment, a healthy or clean work environment will maintain or improve employee performance.

A comfortable, safe and clean work environment will cause or increase work morale, and vice versa a bad work environment will reduce performance. For that the company will need to pay attention and act so that the work environment can be felt in a comfortable, safe, clean manner by employees, so that employee performance will improve. The results of this study are consistent with the research of Putra (2013), Iskandar (2012), Bachtiar (2012) which states that the work environment influences employee performance.

Effect of Motivation on Employee Performance 
Motivation has a significant effect on performance which is the dominant variable influencing performance. The results of this study are consistent with Putra's research (2013), Iskandar (2012), Bachtiar (2012) which states that motivation influences employee performance. Employees who have high work motivation will have the urge to want to use all their abilities to work. Significantly significant $t$ is smaller than $\alpha=0.5(0,000<0.05)$ and has a regression coefficient of 0.636 greater than the work environment. The higher the form of motivation that is given, the higher the level of achievement is motivation is said to be a form of encouragement, encouragement aims to provide enthusiasm that can improve a person's performance, so that in the future can have a high level of performance and can bring the company or organization to an good aim.

A person's motivation at work is usually complicated because motivation includes individual factors and organizational factors. As for the individual factors, namely needs, goals, and abilities. Whereas those belonging to the organization's factors are salary, job security, fellow workers, supervision, praise, and the job itself. Employee motivated or compelled to do a job, the employee will have the passion to do his job, so employees will be able to achieve performance. High and low motivation given by the company to employees will also affect the level of performance obtained by employees, where employees who get high motivation then the performance will also be high. Vice versa if the motivation given to employees is low then the performance will decrease.

\section{Conclusions And Suggestions \\ Conclusion}

- The work environment has a significant effect on employee performance in wood mills

- Motivation has a significant effect on employee performance in wood mills.

\section{Suggestion}

Leaders need to increase employee motivation to further improve their performance and instill a sense of trust in employees and give them freedom to express opinions that may be useful for the company while giving the impression to employees that they are involved in managing the company so that employees will have royalties or more responsible towards the company.

\section{References}

Bachtiar, D. (2011). Effect of Motivation and Work Environment on Employee Performance of Pt. Aqua Tirta Investama in Klaten . Semarang State University.

Iskandar. (2012). The Effect of Motivation and Work Environment on the Performance of Kendal District High School Teachers. Educational Management, 1 (2).

Putra, FR (2013). Effect of Work Environment on Performance. Journal of Business Administration , 6 (1), 1-8.

Samsudin, S. (2010). Human Resource Management . Bandung: Loyal Reader.

Awarmayanti. (2007). Human Resource Management: Bureaucratic Reform and Management of Civil Servants . Bandung: Refika Aditama.

Siagian, S. (2014). Human Resource Management . Jakarta: PT Raja Grafindo Persada. 
International Journal of Economics, Business and Accounting Research (IJEBAR)

Peer Reviewed - International Journal

Vol-4, Issue-1, 2020 (IJEBAR)

E-ISSN: 2614-1280 P-ISSN 2622-4771

https://jurnal.stie-aas.ac.id/index.php/IJEBAR

Sugiyarti, G. (2012). Effect Of Work Environment, Culture Organization And Compensation Of Work Satisfaction To Improve Employee Performance (Study On The Economic Faculty Of August 17, 1945 Semarang). UNTAG Scientific Journal Semarang , 105 (3), 129-133.

Sugiyono (2007). ADMINISTRATION RESEARCH METHOD . (A. Nuryanto, Ed.) (15th ed.). ALFABETA CV.

Sugiyono (2013). STATISTICS FOR RESEARCH (23rd ed.). ALFABETA CV. 